\title{
Merancang Media Hiburan Buku Cergam Menjadi Media Belajar untuk Alat Bantu Komunikasi
}

\author{
Ida Nurhaida, Sugeng P. Hariyanto, \\ Akmal Junaidi, dan Pairul Syah
}

ABSTRACT

\begin{abstract}
For the sake of reinforcing the local knowledge (that seems to be abandoned by local community of West Lampung themselves) and to make corrections against agroforestry malpractices as well as of accommodating to the poor performance of extension programs on recharge area of West Lampung (including of media lacking of extension), we have developed the entertainment media of pictorial story books of coffee agroforestry. The media were designed especially

for the low literate community (Nurhaida et al., 2004) to affirm the tao of knowledge of the four tribes dwell in the recharge area: Lampungese, Semendonese, Sundanese and Sundanese of villages of Way Mengaku, Sukananti, Sidomakmur and Gunung Terang respectively (see

Nurhaida et al., (2005). There are four languages edition in accordance with the locally mother tongues of the four tribes plus Indonesian to accommodate the other tribes exist in West Lampung. Desk activities were conducted at the Laboratory of Multimedia, Department of Communication Science, The University of Lampung Indonesia. Media pretesting were conducted twice in August-September 2005 to measure the variables of attraction, self involvement, acceptability and comprehension of the media in accordance with Bertrand's suggestion (1978). Between the two and the second of the media pretesting, there had been conducted the media improvements. The research showed that the entertainment media have been used up to be a learning media for the propose of extension program in the recharge area successfully. This claim is supported by the high effectiveness of the five editions: (Lampungese, Semendonese, Javanese, Sundanese and Indonesian of 85, 89, 88, 89, and 86\% repectively) that brookthrough aggaints the severely heavied barrier of low litteracy : 27, 44, 39, 77, dan 88 words per second respectively. It is strongly recommended that: (1) reproduce the media and disseminate into community $d$ well on the recharge of West Lampung to reinforce the tao of knowledge, and (2) conduct the similar research on other recharge areas.
\end{abstract}

Kata kunci: buku cerita bergambar, media pembelajaran

\section{Pendahuluan}

Penggunaan gambar untuk memperjelas isi pelajaran dipelopori John Amos Comenius sebagaimana dimuat dalam bukunya, The Visible of World di tahun 1653, yang pada awalnya digunakan untuk pendidikan anak-anak. Kemudian penggunaan ini berkembang menjadi media hiburan seperti komik, kartun, fotonovela, dan buku cerita bergambar. Sebagaimana halnya komik, buku cerita bergambar merupakan suatu bacaan yang dilengkapi dengan gambar atau ilustrasi untuk memperjelas isinya. Pada perkembangan awal media ini lebih banyak digunakan untuk keperluan hiburan yang bertemakan dongeng, fabel, kisahkisah, satir, dan karikatur. Karena formatnya yang 
fleksibel untuk mengemas berbagai tema, dalam tiga dekade terakhir ini media tersebut mulai digunakan untuk mengemas pesan-pesan pembangunan.

Studi yang dilakukan oleh Parlato, Parlato, dan Cane (1980) di negara-negara Asia Selatan, Amerika Latin, dan Afrika, ternyata dengan media ini umumnya dapat digunakan dengan hasil yang sangat mengesankan untuk menyampaikan pesanpesan pembangunan mengenai nutrisi, kesehatan, keluarga berancana, dan demografi pada masyarakat yang rendah tingkat literasinya. Buku cerita bergambar atau cergam, pada dasarnya, adalah suatu media grafis berupa bacaan yang berisi pesan-pesan berbentuk literal yang dilengkapi dengan gambar atau ilustrasi untuk memperjelas isi pesan-pesannya.

Buku cergam mempunyai kesamaan dengan komik, utamanya pada realitas gambar yang digunakan. Cergam dan komik menggunakan gambar-gambar dengan realitas sedang, yang berbeda dengan fotonovela yang menggunakan gambar dengan realitas tinggi berupa foto-foto sesuai dengan keadaan aslinya (lihat Parlato dkk., 1980). Cergam berbeda dengan komik dan fotonovela utamanya terletak pada sekuen gerakan yang tidak ada pada cergam. Adanya persamaan dan perbedaan ini berimplikasi pada penggunaannya untuk kepentingan penuangan pesan garfis. Implikasi ini menjadi makin penting manakala ketiga media itu bukan hanya digunakan sebagai media hiburan semata tetapi juga untuk media belajar utamanya pada khalayak yang rendah tingkat literasinya (Lionberger dan Gwin, 1982).

Belajar, secara umum, dapat diartikan sebagai proses dari tidak tahu menjadi tahu. Dalam pandangan kaum behaviorist, setiap perilaku manusia merupakan hasil belajar, sehingga perilaku manusia berkembang dan termodifikasi dari perilaku masa lalu. Modifikasi itu akan kuat dan permanen manakala pengalaman masa lalu itu menyenangkan (gratifiying). Pengalaman yang menyenangkan cenderung diulang, dan pengalaman yang tidak menyenangkan cenderung dihindari. Dengan begitu, belajar akan mengukuhkan perilaku. Dengan menggunakan framework dari kaum behaviorism ini, maka keberhasilan pemanfaatan media hiburan grafis yang menyenangkan (seperti dilaporkan Parlato dkk., 1980) itu antara lain dapat dijelaskan.

Setelah karya Parlato dkk. (1980) yang monumental tersebut, kemudian mulai banyak dijumpai penggunakan media grafis ini untuk kepentingan komunikasi seperti untuk pengembangan kesehatan misalnya, Michielutte dkk. (1992), Delp dan Jones (1996), Dowse dan Ehlers (2001), Simth dan Stutt (2003), Houts dkk. (2006), dan lain-lainnya. Untuk kepentingan komunikasi instruksional, media grafis juga banyak digunakan untuk bidang penalaran dan bidang kuantitatif mahasiswa, seperti untuk ilmu fisika (Gonick dan Huffman, 1991), untuk genetika (Gonick dan Mark, 1992), serta untuk statistika (Gonick dan Smith, 1993).

Di Indonesia, menurut Zeffry (2001), media ini umumnya lebih banyak digunakan untuk keperluan hiburan termasuk dalam bentuk karikatur dalam surat-surat kabar. Walaupun begitu, pada dua dekade terakhir ini, di Indonesia, beberapa peneliti melaporkan penggunaan berbagai media grafis ini juga efektif untuk menyampaikan pesanpesan pembangunan, seperti Satmoko (1995), Retowati (1995), Nugraha (1995), Nurhaida (1995, 1999), Linda dkk., (1996), dan Nurhaida (1999), Nurhaida dkk. (2001, 2005b), serta Febrianto dan Rafdinal (2006). Bahkan, pada masyarakat yang sangat rendah tingkat literasinya (kemampuan membaca sekitar 15-18 kata per menit) di dua desa di Majalengka Jawa Barat dengan media cergam, Nurhaida (1999) dan Nurhaida dkk. (2001) menunjukkan adanya peningkatan pengetahuan petani secara nyata tentang pertanian konservasi di lahan kering. Namun, melalui penelusuran referensi secara mendalam (termasuk dengan internet), tidak dijumpai penggunaan media ini untuk komunikasi pembangunan wanatani (agroforestry). Padahal, media ini sangat potensial bila dimanfaatkan untuk pendifusian kultur teknis wanatani di wilayah resapan di seperti Lampung Barat, terutama bila dikaitkan dengan permasalahan fisik wilayah, masalah sosial, ekonomi, budaya, serta literasi yang ada di wilayah ini.

Secara fisik, menurut Pusat Penelitian Tanah 
dan Agroklimat (1989), fisiografi Lampung Barat utamanya mempunyai bentang alam (landscape) perbukitan dan pegunungan (orografik) dengan kemiringan lahan rata-rata yang cukup curam, curah hujan yang besar (2833-3058 mm per tahun), didominasi tanah yang peka erosi. Menurut Departemen Kehutanan (2000), sekitar 30\% wilayah Lampung Barat status kepemilikan lahannya ditetapkan sebagai hutan milik negara untuk hutan produksi terbatas dan hutan lindung yang berfungsi sebagai wilayah peresapan air, tetapi realitas penggunaan lahan yang ada, menurut Afandi dkk. (2002), berupa tanaman kopi yang umumnya ditanam secara monokultur. Artinya, sebagian besar telah dirambah. Padahal, di bagian Tengah, telah banyak direncanakan dan dibangun berbagai fasilitas dengan investasi yang sangat mahal (seperti dam, bendungan, pembangkit tenaga listrik, dan jaringan irigasi), baik sejak pemerintahan kolonial maupun semasa Pemerintahan RI, yang sangat penting untuk menopang keberlanjutan sistem ekologi manusia yang terkonsentrasi bagian Tengah dan di bagian Timur Propinsi Lampung.

Realitas sosial dan budayanya menurut, Nurhaida dkk. (2005), di wilayah resapan ini ada empat etnis yang dominan, yaitu Semendo, Lampung, Jawa, dan Sunda. Dua etnis pertama merupakan etnis asli (yang mempunyai berbagai kearifan lokal dan berbudidaya kopi di wilayah hutan) dan dua etnis lainnya merupakan etnis pendatang melalui program transmigrasi (Biro Rekonstruksi Nasional pada masa Pemerintahan Sukarno tahun 1955), yang tidak mempunyai latar belakang pertanian kopi, melainkan pertanian palawija pada bentang lahan yang umumnya datar pula. Tetapi, ternyata, kearifan lokal itu semakin banyak ditinggalkan (oleh etnis asli sekalipun), sehingga pertanian kopi secara monokultur mejadi dominan di wilayah ini. Fenomena ini menyebabkan kemerosotan fungsi hidro-orologis wilayah resapan ini semakin berat, yaitu fluktuasi debit yang besar, (banjir berlumpur sedimen pada musim hujan dan kekeringan di musim kemarau). Di beberapa tempat, banyak ditemukan wilayah yang rawan longor akibat aliran air permuakaan tanah (run off) dan laju erosi tanah melampaui ambang batas, seperti dilaporkan oleh Afandi dkk. (2002b).

Untuk itu, pengukuhan (reinfocement) kepada etnis asli dan pendifusian kepada etnis pendatang atas berbagai kearifan lokal dalam bidang wanatani ini, yang telah mulai banyak ditinggalkan tersebut, mendesak untuk dilakukan melalui suatu program komunikasi penyuluhan. Hendaknya program itu juga meliputi upaya-upaya untuk melakukan koreksi atas praktek-praktek wanatani kopi yang keliru dan bertentangan (conflicting) terhadap pengetahuan ilmiah yang juga banyak dilakukan oleh para petani setempat.

Sementara itu, secara konsepsional wanatani dapat diartikan sebagaimana yang dimaksudkan oleh Arsyad (2000), yaitu setiap sistem penggunaan lahan untuk menyediakan kayu, hasil tanaman pepohonan, dan semak yang merupakan pertanaman campuran, yang tersusun secara spasial dengan ataupun tanpa hewan. Tanaman tahunan berkayu tersebut ditanam untuk lebih dari satu tujuan, bersama-sama dengan tanaman berbentuk semak dan rerumputan, sehingga terbentuk sistem penanaman dengan berbagai strata ketinggian tajuk (multistrata). Ini dapat memaksimumkan penangkapan sinar matahari, memaksimumkan perlindungan permukaan tanah terhadap tumbukan butir-butir air hujan secara langsung, mencegah kehancuran struktur tanah, memaksimumkan peresapan air hujan ke dalam tanah, sekaligus meminimumkan aliran air di permukaan, menekan laju erosi tanah, meminimumkan kehilangan unsur hara, yang berarti pula dapat meminimumkan masukan seperti pupuk dan sebagainya. Dengan demikian, hal ini dapat mencegah kerusakan lingkungan, dapat meningkatkan keanekargaman hayatinya serta dapat memberikan amenitas lingkungan. Sedangkan secara lebih praktikal, menurut Joshi dkk. (2001), wanatani dapat diartikan sebagai menanam tanam pertanian di antara tanaman pepohonan berkayu di wilayah hutan.

Apabila program pengukuhan dan redifusi kultur teknis wanatani itu banyak diadopsi oleh para petani kopi di Lampung Barat, maka bisa 
menjadi tumpuan harapan bagi pelestarian wilayah resapan ini. Tetapi, kinerja penyuluhan di wilayah ini belum memperlihatkan hasil yang nyata akibat keterbatasan jumlah dan frekuensi penyuluhan termasuk juga penyediaan alat bantu komunikasi yang handal Nurhaida dkk (2005). Kecuali itu, Nurhaida dkk (2004) juga melaporkan persoalan sangat mendasar bahwa kemampuan literasi (readability) dari keempat etnis ini juga tergolong sangat rendah, yaitu berkisar 22 sampai 88 kata per menit. Mengingat readability masyarakat perdesaan dalam waktu yang relatif singkat tidak mudah untuk ditingkatkan, maka tantangan besar yang harus dihadapi oleh para ahli komunikasi pembangunan adalah untuk merancang media grafis yang dapat menembus barrier literasi yang berat tersebut di samping untuk menembus hambatan sosialkultural lainnya.

Berkaitan dengan permasalahan rendahnya tingkat literasi tersebut, selain masalah fisik, ekonomi, sosial, dan budaya yang ada di Lampung Barat ini, dikaitkan pula dengan bukti-bukti keefektifan media grafis untuk berbagai program komunikasi di masyarakat yang rendah tingkat literasinya tersebut di atas, maka media buku cergam perlu dipromosikan fungsinya agar dapat digunakan sebagai media belajar dan alat bantu komunikasi penyuluhan tentang kultur teknis wanatani kopi di wilayah resapan ini. Kecuali itu, pertimbangan lain yang juga menguatkan usulan promosi itu, antara lain, formatnya yang sangat mudah untuk dimuati dengan berbagai pesan ideologi lingkungan, citra dan popularitasnya yang masih baik di kalangan warga perdesaaan sebagai media hiburan, durabilitasnya yang relatif panjang (dibandingkan radio dan televisi) sehingga mudah diulang-ulang berkali-kali oleh sesama warga masyarakat, relatif mudah direproduksi dan murah dalam penggandaannya (Nurhaida dkk, 2001).

Berdasarakan latar belakang dan masalah yang diseneraikan di atas, maka perlu dilakukan penelitian ini dengan tujuan untuk merancang media hiburan buku cergam menjadi media belajar yang sekaligus dapat dimanfaatkan untuk alat bantu komunikasi penyuluhan yang andal, yang kompatibel dengan latar belakang: secara fisik (wilayah resapan yang fragil dan terpencil); ekonomi (mata pencaharian utama pertanian kopi di kawasan hutan); sosial dan budaya (ada empat etnis dominan lengkap beserta berbagai kearifan lokal selain keterbelakangannya, adat dan kebiasaan setempat); dan yang mampu untuk menembus barrier yang sangat berat berupa rendahnya tingkat literasi masyarakat.

\section{Metode Penelitian}

Penelitian ini merupakan penelitian tahun ke-2 dari 3 tahap penelitian yang dibiayai oleh Direktorat Pembinaan Penelitian dan Pengabdian kepada Masyarakat (DP3M) Dirjen Dikti Tahun Anggaran 2004-2006 yang dilaksanakan mulai bulan April sampai Oktober 2005. Penelitian ini terdiri atas penelitian lapang dan aktivitas laboratorium. Penilitian lapang dilakukan di empat desa/dusun yang sesuai dengan etnis dominan, yaitu Etnis Lampung (Way Mengaku Kecamatan Balik Bukit), Etnis Semendo (Sukananti Kecamatan Way Tenong), Etnis Jawa (Sidomakmur Kecamatan Way Tenong) dan Etnis Sunda (Gunung Terang Kecamatan Pajar Bulan) di Kabupaten Lampung Barat. Aktivitas laboratorium dilakukan di Laboratorium Multimedia Jurusan Ilmu Komunikasi FISIP Universitas Lampung.

\section{Pengembangan Media Cergam}

\subsection{Substansi Isi Pesan}

Substansi isi pesan diekstrak dari hasil-hasil penelitian tahun pertama yang sangat esensial bagi kampanye pelestarian wilayah resapan di Lampung Barat(Nurhaida dkk, 2005a). Lebih lanjut, mengingat media komunikasi ini juga dimaksudkan untuk mengukuhkan praktik-praktik wanatani kopi yang sudah benar atau sejalan dengan pengetahuan ilmiah (kearifan lokal) yang mulai banyak ditinggalkan khalayak aslinya pun dan untuk mencegah kekeliruan berikutnya yang mungkin dilakukan oleh petani, maka perancangan isi pesan perlu difokuskan pada kedua aspek tersebut.

Praktek-praktek kearifan lokal yang ditemukan dalam empat etnis di Lampung Barat itu (lihat Nurhaida dkk., 2005a) dijadikan sebagai isi pokok pesan yaitu 
meliputi: (a) praktik pemilihan benih tanaman kopi, penentuan jarak tanam kopi, dan jarak tanaman peneduh, dan sistem penanaman secara multistrata berbagai jenis tanaman dari keempat etnis tersebut; (b) praktik olah tanah minimum dan penghamparan sisa-sisa tanaman pada permukaan lahan (praktik pemulsaan atau mulching) dari Etnis Lampung dan Semendo yang juga perlu diperkenalkan pada Etnis Jawa dan Sunda; (c) praktik penanaman kacangkacangan (LCC: legume cover cropping) perlu dikukuhkan pada Etnis Jawa dan diperkenalan kepada ketiga etnis lainnya; (d) praktik peremajaan tanaman kopi dengan kapak kulai (Etnis Semendo) atau tuakh sarakh (Etnis Lampung) dan pungkak serta stek perlu dikukuhkan pada kedua etnis tersebut dan diperkenalkan pada Etnis Jawa dan Etnis Sunda; (e)praktik pemeliharaan hewan ternak seperti domba, itik, angsa dan ayam (Lampung, Jawa, Sunda), serta pemeliharaan ikan (Sunda) perlu dikukuhkan dan diperkenalkan kepada Etnis Semendo. Praktik-praktik yang keliru yang harus dicegah adalah: (a) praktik land clearing, menebang pohon-pohon hutan, dan membakar sisa-sisa tanaman dan sangat meluas pada emapt etnis yang ada, dan (b) praktek pengolahan tanah secara intensif ataupun pembersihan sisa-sisa tanaman (Jawa).

\section{2 "Story Board" dan "Setting" Cerita}

Substansi isi pesan yang telah diekstrak tersebut dituangkan dalam suatu cerita yang didahului dengan brainstorming di antara tim peneliti. Hasil brainstorming itu juga menyimpulkan ada 20 topik yang perlu diskenariokan dalam story board. Selain esensi isi pesan, untuk memperoleh media komunikasi yang andal, maka latar belakang sosial, ekonomi, budaya, dan latar belakang fisik yang melingkupi wilayah resapan ini juga dimanfaatkan secara eksploratori. Untuk itu, setting cerita mengambil realitas fisik di wilayah resapan di Lampung Barat, dengan menggunakan empat desa/dusun yang didominasi oleh masing-masing etnis Lampung, Semendo, Jawa, dan Sunda, yaitu Desa Way Mengaku, Sukananti, Sidomakmur, dan Gunung Terang. Empat tokoh juga digunakan untuk masing-masing etnis tersebut yang diskenariokan dalam suatu situasi permasalahan kemerosotan hasil panen kopi yang terus berlanjut, ketidakmenentuan informasi, upaya-upaya pencarian jawaban, konfirmasi, atribusi, dan solusi tentang agroekosistem pertanian kopi di wilayah resapan. Selain kearifan lokal, wanatani (agroforestry) kopi yang absah secara saintifik merupakan pesan inovasi kunci yang dijadikan fokus dalam mengatasi kemerosotan produktivitas lahan di wilayah resapan, yang sekaligus juga bertalian dengan pencegahan kerusakan lingkungan di wilayah hilir secara tersistem dan terintegrasi sebagai satu kesatuan.

Empat bahasa daerah tersebut digunakan untuk memudahkan pemahaman. Mengingat Lampng Barat juga merupakan melting pot bagi suku-suku lain, seperti Bali, Batak, dan Padang, maka juga dilengkapi edisi Bahasa Indonesia. Praktik-praktik adat setempat yang tidak bertentangan dengan pencegahan kerusakan lingkungan seperti syukuran panen agung ngumbai dan penentuan saat tanam menurut anatomi bagian tanaman (dari Etnis Lampung), adat pewarisan harta kepada anak perempuan tertua atau tunggu tubang dan penentuan saat tanam menurut kala revolusi rasi bintang (dari Etnis Semendo) juga dimanfaatkan dalam penuangan kedalam cerita untuk meningkatkan keterlibatan diri (self involvement) dari khalayak.

Berbagai pertimbangan tersebut dimaksudkan agar dapat dihasilkan media hiburan buku cergam tersebut menjadi media belajar yang mempunyai keempat unsur keefektifan media yang tinggi di dalam kendala (contraint) hambatan literasi dan hambatan fisik wilayah serta hambatan sosialkultual yang ada lainnya.

\section{Rancangan Fisik Cergam}

\subsection{Desain Gambar Sampul dan Halaman-halaman Isi Cergam}

Rancangan atau desain sampul memegang peranan yang sangat strategis bagi keberhasilan proses komunikasi visual seperti cergam. Untuk media hiburan seperti buku cergam, sampul 
merupakan eye catcher, daya tarik (attraction) dari sampul, bisa sangat menentukan apakah media hiburan ini menarik untuk dibaca ataukah ditinggalkan. Tidak ada rumusan umum untuk merancang format visual dari suatu sampul cergam, tetapi untuk meningkatkan kertelibatan diri (self involvement) bagi khalayak sasaran, maka idealya sampul cergam mampu mengekspresikan isinya secara keseluruhan. Karena itu, dalam penelitian ini, isi pesan sampul disarikan dari keduapuluh topik pesan yang dituangkan halamanhalaman cergam. Untuk itu, maka juga telah dilakukan brainstorming tentang rancangan sampul di antara tim peneliti. Kegiatan braistorming ini juga dilakukan untuk merancang sketsa dan skript gambar-gambar visual tiap halaman cergam untuk meningkatkan daya tariknya (attraction) dan pemahamannya (comprehension) khalayak sasaran. Pada fase ini disepakati judul buku cergam: Melestarikan Wilayah Resapan dengan Menerapkan Wanatani Kopi.

Gambar sketsa dibuat secara manual dengan cat air oleh Nurhaida. Selanjutnya, diserahkan kepada pelukis profesional untuk dibuat draft akhir gambar-gambar keseluruhan, berupa cat air pada kertas manila putih. Mengingat perannya yang sangat strategis itu, maka gambar sampul dibuat lima macam pilihan, untuk dipilih satu yang terbaik oleh khalayak petani di empat desa/dusun penelitian ini untuk dijadikan gambar sampul final. Sedangkan gambar atau ilustrasi yang digunakan pada tiap halaman cergam dibuat satu sampai dua gambar per halaman untuk memperjelas isi pesan. Semua draft gambar (hasil lukisan pelukis profesional tersebut) direproduksi dengan kamera digital HP dengan kemampuan 2 megapixel kemudian diedit dalam Photo Editor 7.0 yang selanjutnya untuk disisipkan pada halamanhalaman cergam.

\subsection{Tata Letak}

Tata letak (lay out) mengadaptasi media cergam yang telah dikembangkan Nurhaida (1999) dan Nurhaida dkk. (2001). Atas dasar pertimbangan kemampuan literasi, realitas fisik wilayah dan sosial budaya yang ada, maka ada 20 substansi pesan yang perlu dituangkan ke dalam media cergam dengan satu topik pesan per halaman. Separo halaman bagian bawah digunakan untuk pesan literal. Sisanya, bagian atas digunakan untuk pesan visual untuk meningkatkan pemahaman dan daya tarik serta pelibatan khalayak pembacanya. Di bawah bidang gambar, dibuat subjudul yang mewakili satu topik pesan. Pesan literal dituangkan kedalam narasi ataupun percakapan pendek dengan menggunakan 10 sampai 15 kalimat per halaman. Untuk menghindari timbulnya kesan rumit, sekaligus untuk meningkatkan daya tarik (attraction), maka dipilih huruf tanpa kait, yaitu Arial dengan ukuran 14 font.

\section{3 "Draft" Buku Cergam}

Draft sampul buku cergam dicetak dengan printer Canon Pixma iP 3000, pada kertas tulip krem, berukuran $21 \mathrm{~cm} \mathrm{X} 24 \mathrm{~cm}$. Untuk halamanhalaman isi cergam, digunakan kertas crommo 80 gram. Untuk keperluan ujicoba, setiap edisi bahasa dicetak secara terbatas sebanyak 25 eksemplar.

\section{Uji Coba Media}

\subsection{Uji Coba dan Perbaikan Media}

Uji coba media (media communication pretesting) dilakukan berdasarkan saran Bertrand (1978) seperti yang telah dilakukan oleh Nurhaida (1999) dan Nurhaida dkk (2001). Uji coba ini dilakukan dua kali pada bulan Agustus-September 2005 diantarai dengan kegiatan perbaikan media (media improvement).

\subsection{Uji Coba Efektivitas Media}

Dari tiap desa/dusun dipilih sekitar 20 orang responden sampel. Sebanyak 10 orang "diberikan" (dipersilakan ambil) buku cergam edisi Bahasa Indonesia, dan sekitar 10 orang edisi bahasa daerah setempat, untuk dibaca di tempat secara bersamaan. Kemudian diberikan dua macam kuesioner. Kuesioner pertama untuk menguji pemahaman (comprehension) terhadap substansi isi pesan. Kuesioner ke dua untuk mengukur 3 variabel keefektifan media cergam lainnya yaitu 
daya tarik (attraction), keterlibatan (selfinvolvement), dan penerimaan (acceptability). Pada bagian akhir dari kuisener yang ke dua ini, juga dilengkapi kolom saran-saran perbaikan.

Untuk menguji pemahaman maka disajikan 25 pertanyaan pilihan berganda dengan kemungkinan jawaban benar/salah. Nilai pemahaman responden ditentukan dengan persentase jawaban yang bernilai benar. Uji terhadap 3 variabel keefektian media yang lain, masing-masing disidik dengan menggunakan 4 buah pertanyaan, yang mempunyai 3 pilihan kemungkinan jawaban sebagai skala sikap. Untuk pilihan jawaban a yaitu benar/sesuai dengan harapan diberi skor 3 , untuk pilihan jawaban $b$ yaitu sebagian benar/sebagian sesuai diberi skor 2 , untuk pilihan jawaban $c$ yaitu tidak benar/tidak sesuai diberi skor 1. Dengan demikian nilai harapan terbesar adalah 12 untuk tiap orang tiap variabel.

Misalkan, seorang sampel/partisipan memberikan jawaban terhadap variabel daya tarik (attraction) pada pertanyaan pertama dia memberikan jawaban $b$, pertanyaan ke dua dengan jawaban $b$, pertanyaan ke tiga dengan jawaban $c$, serta untuk petanyaan ke empat dengan jawaban $a$. Maka bagi satu orang ini daya tarik media yang dia baca $=\{(2+2+1+3) / 12\} \times 100 \%=75 \%$. Nilai variabel daya tarik (attraction) media ini untuk 25 orang sampel berarti rata-rata dari 25 orang. Demikan pula variabel keterlibatan (involvement), dan penerimaan acceptability), ditentukan dengan cara seperti penentuan daya tarik (attraction) dari media ini.

Keefektifan media bagi seorang partisipan/ sampel merupakan rataan dari keempat variabel tersebut. Misalkan untuk keempat variabel (pemahaman, daya tarik, keterlibatan, dan penerimaan) masing-masing $80 \%, 80 \%, 85 \%, 75 \%$, maka keefektifan media ini bagi seorang partisipan/ sampel tersebut adalah $80 \%$. Keefektifan media setiap edisi bahasa diperoleh dari rata-rata semua sampel tiap desa/dusun.

\subsection{Ujicoba Desain Sampul}

Ujicoba draft desain sampul ini dimaksudkan untuk memilih satu dari lima draft sampul yang terbaik menurut pilihan khalayak. Tiap orang partispan/sampel, diminta untuk memilih salah satu draft sampul yang terbaik dari lima draft yang telah disiapkan. Uji ini dilakukan sesaat setelah ujicoba keefektifan media cergam dilakukan pada orangorang yang sama pula. Rancangan draft sampul yang dipilih terbanyak, diputuskan untuk digunakan sebagai sampul final media cergam ini.

\subsection{Perbaikan Media}

Perbaikan utamanya dilakukan pada pesanpesan literal, khususnya untuk edisi yang mempunyai skor dibawah 70. Perbaikan pesan visual dilakukan secara minor. Dasar utama bagi perbaikan ini adalah saran-saran dari responden yang dijaring sesaat setelah ujicoba media. Setelah perbaikan media (media improvement) ini maka dilakukan uji keefektifan media yang ke dua.

\section{Hasil dan Pembahasan}

\subsection{Pilihan Desain Sampul}

Lima draft sampul yang telah dikembangkan disajikan pada Gambar 1. Beberapa halaman cergam yang digunakan dalam penelitian ini disajikan pada Gambar 2. Hasil ujicoba draft desain sampul disajikan pada Tabel 1.

Tabel 1.

Jumlah Vote dan Ranking Hasil Ujicoba Desain Draft Sampul Buku Cergam di 4 Desa/Dusun Penelitian

\begin{tabular}{|l|llllll|}
\hline \multirow{2}{*}{ No. Desa/Dusun } & \multicolumn{5}{|c|}{ Desain } \\
\cline { 3 - 7 } & I & II & III & IV & V \\
\hline 1 & Way Mengaku & 1 & 1 & 11 & 5 & 3 \\
\hline 2 & Sukananti & 3 & 2 & 6 & 6 & 2 \\
\hline 3 & Sidomakmur & 2 & 1 & 11 & 5 & 1 \\
\hline 4 & Gunung Terang & 2 & 2 & 9 & 3 & 3 \\
\hline & Jumlah Vote: & 8 & 6 & 37 & 19 & 9 \\
\hline Rangking: & $\mathbf{4}$ & $\mathbf{5}$ & $\mathbf{1}$ & $\mathbf{2}$ & $\mathbf{3}$ \\
\hline
\end{tabular}

Sumber: Hasil Penelitian (2005) 


\section{Gambar 1. Lima Pilihan Rancangan Sampul Cergam}

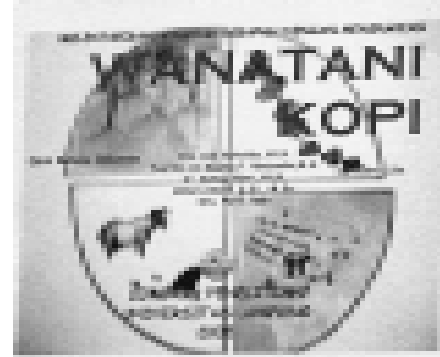

I

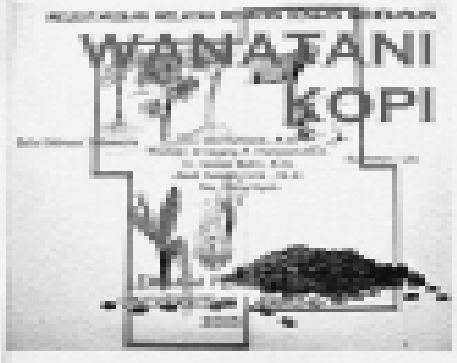

II

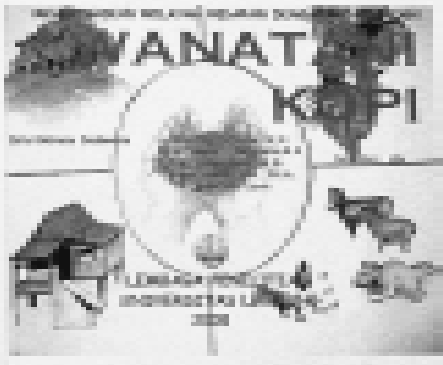

II

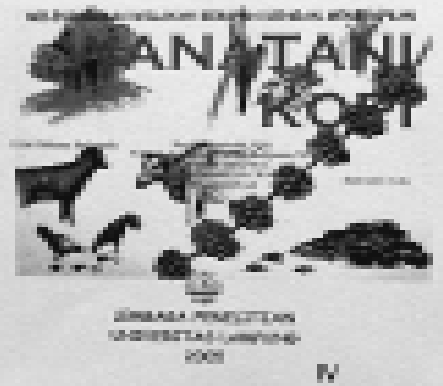

N

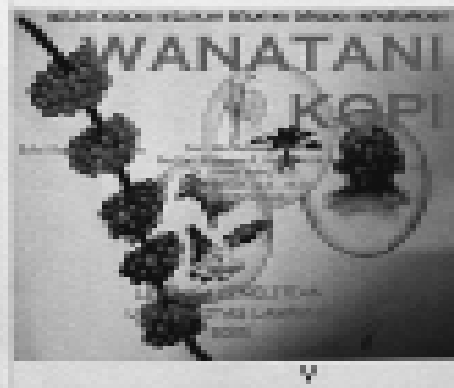

Sebagaimana dapat dilihat pada Tabel 1 tersebut, desain III merupakan rancangan sampul yang paling disukai khalayak. Desains III pada semua desa/dusun tempat penelitian mendapatkan suara terbesar kecuali di Desa Sukananti, desain ini dipilih dengan suara yang sama banyak dengan rancangan II. Tampaknya, desains III ini, lebih menarik, lebih representatif dan lebih menyenangkan bagi khalayak setempat. Dalam desains III ini unsur bentuk atau obyek rumah adat setempat merupakan satu-satunya obyek yang tidak terdapat pada empat desain yang lain. Objek ini, tampaknya, menjadi pembeda terhadap desain lainnya, yang mampu membangkitkan rasa keterlibatan khalayak. Walaupun begitu, sebagaimana terhadap material hasil seni umumnya, apresiasi terhadap realitas itu tidak bisa diklaim sebagai penilaian yang pasti. Perlu kajian yang lebih mendalam terutama dikaitkan dengan manfaat untuk meningkatkan daya tarik (attraction) bagi produk desain visual komunikasi cetak bagi khalayak atau masyarakat perdesaan.

\subsection{Keefektifitan Media sebagai Media Belajar}

Efektivitas media buku cergam sebagai media belajar ataupun alat bantu komunikasi penyuluhan dalam penelitian ini diekspresikan dengan menggunakan empat varibael (Bertrand, 1978), yaitu daya tarik (attraction), keterlibatan diri (self involvement), penerimaan (acceptability), dan pemaham (comprehesion). Efektivitas media merupakan rataan dari keempat variabel ini. Secara ringkas, hasil akhir keefektifan cergam sebagai media belajar, ataupun sebagai alat bantu komunikasi penyuluhan, untuk keempat desa penelitian ini disajikan pada Tabel 2. Untuk memudahkan apresiasi terhadap hasil pengukuran keefektifan media tersebut, maka dilengkapi dengan data literasi khalayak (Nurhaida dkk., 2004) seperti disajikan dalam kolom 3 Tabel 2.

Seperti dapat dilihat pada Tabel 2, ujicoba media pertama (hasilnya dinyatakan sebagai angka-angka dalam tanda kurung) bahwa variabel 


\section{Gambar 2. Beberapa Contoh Halaman Buku Cergam Wanatani Kopi}
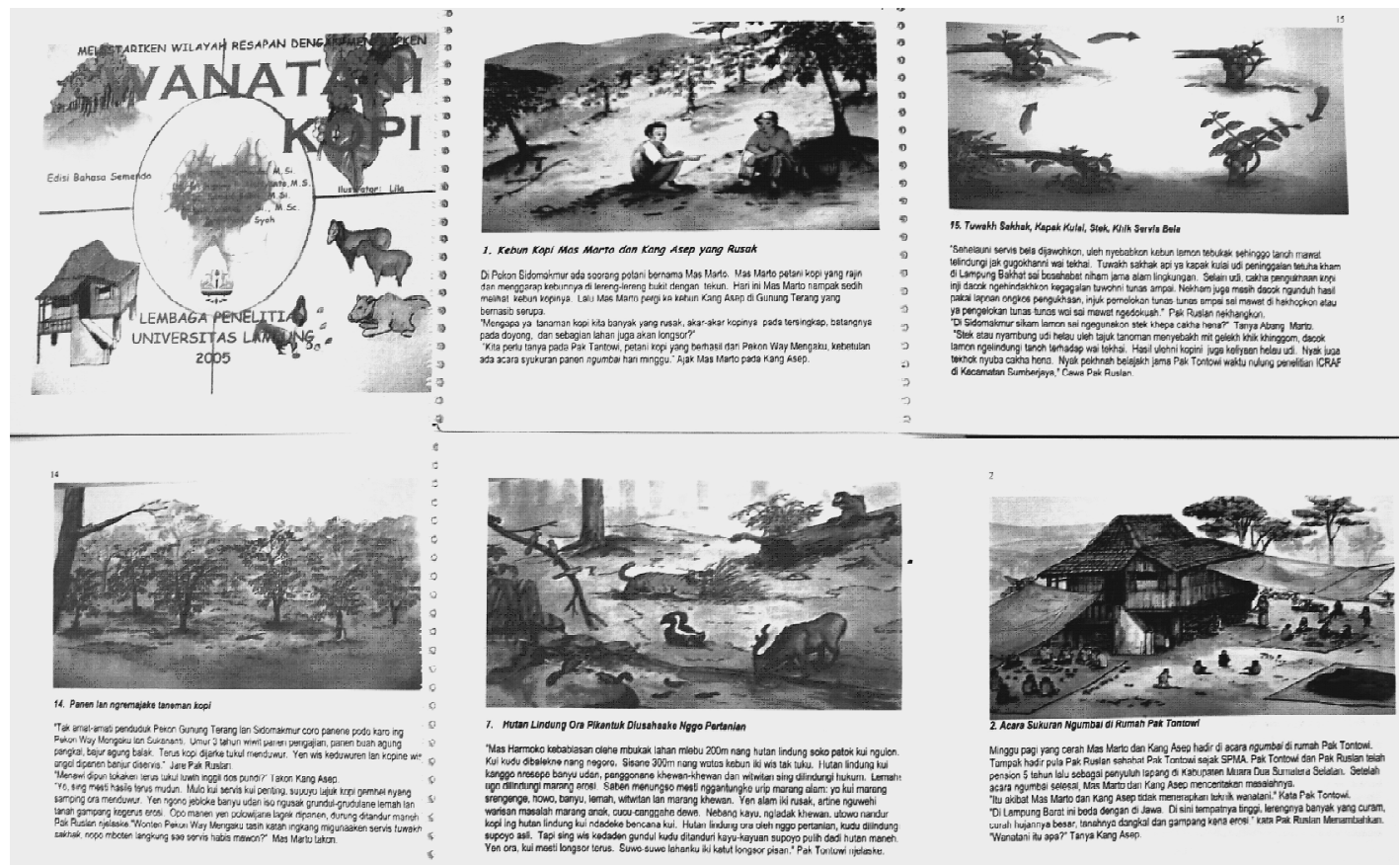

daya tarik, keterlibatan, dan penerimaan media umumnya sudah tergolog tinggi. Namun, variable pemahaman (comprehension), yang merupakan variabel sangat penting bagi kriteria keefektifan
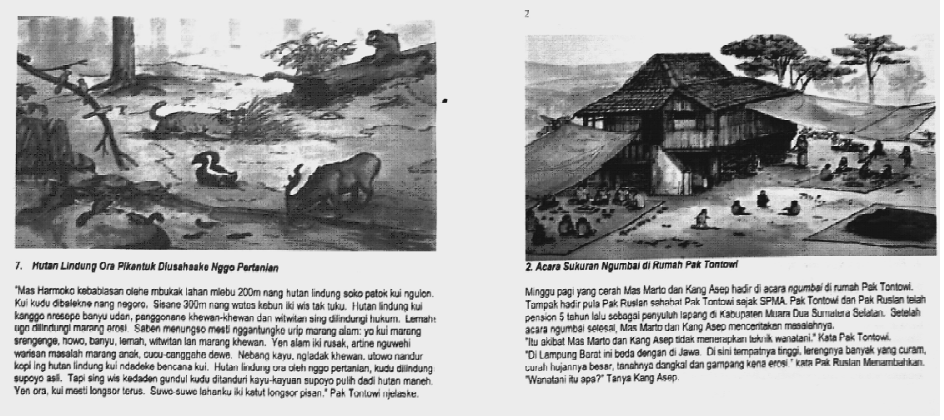

Tabel 2. Hasil Ujicoba Pertama dan Ke dua (dalam tanda kurung) Efektivitas Buku Cergam tentang Wanatani Kopi sebagai Media Belajar pada 4 Desa/Dusun Penelitian di Lampung Barat

\begin{tabular}{|l|c|c|c|c|c|c|}
\hline No. Edisi & $\begin{array}{c}\text { Keterbacaan* } \\
\text { Kata/menit }\end{array}$ & Daya Tarik & Pelibatan & Penerimaan & Pemahaman & $\begin{array}{c}\text { Keefektifan** } \\
(\%)\end{array}$ \\
\hline 1. Bahasa Indonesia*** & 88 & $93(84)$ & $87(88)$ & $88(86)$ & $76(71)$ & $86(82)$ \\
\hline 2.. Bahasa Lampung & 27 & $97(76)$ & $98(76)$ & $70(64)$ & $75(60)$ & $85(69)$ \\
\hline 3. Bahasa Semendo & 77 & $97(80)$ & $88(80)$ & $95(92)$ & $81(70)$ & $89(83)$ \\
\hline 4. Bahasa Jawa & 44 & $94(80)$ & $97(90)$ & $88(88)$ & $76(68)$ & $89(82)$ \\
\hline 5. Bahasa Sunda & 39 & $87(86)$ & $95(90)$ & $93(90)$ & $77(66)$ & $88(83)$ \\
\hline
\end{tabular}

Sumber : Hasil Penelitian (2005)

Keterangan: * Nurhaida dkk. (2004).

** Rataan dari hasil uji pada empat desa/dusun

*** Rataan dari daya tarik, keterlibatan, penerimaan dan pemahaman.

( ) Hasil ujicoba media yang pertama, yaitu sebelum dilakukan perbaikan. 
sedang sampai tinggi (berkisar 69 sampai 83\%), maka belum bisa dinilai layak sebagai media belajar yang efektif berhubung dengan masih rendahnya variabel pemahaman tersebut.

Pada ujicoba media yang pertama itu, juga diketahui bahwa edisi Bahasa Lampung mempunyai keefektifan media yang paling rendah yaitu 69\%. Ini terutama disebabkan oleh rendahnya penerimaan (acceptability) dan rendah pemahaman (comprehension) media ini. Sebagaimana dapat diindentifikasi dari saran-saran responden pada hasil ujicoba media yang pertama itu, realitas ini terjadi karena kesalahan dalam memilih rumpun Bahasa Lampung yang digunakan. Lampung Barat, utamanya, didiami oleh etnis Lampung dengan penutur berdialek Ouy, sementara itu yang digunakan adalah dialek Api. Informasi ini tidak diperoleh sebelum dilakukan ujicoba media yang pertama itu. Karena kesalahan itu, maka hal itu menyebabkan variabel penerimaan (acceptability) mereka menjadi rendah dan yang menjadi barrier bagi pemahaman (comprehension)-nya.

Setelah dilakukan perbaikan media, maka variabel pemahaman pada edisi Bahasa Lampung meningkat secara rata-rata menjadi $75 \%$ pada ujicoba media yang ke dua, seperti dapat dilihat pada Tabel 2 pada angka-angka yang ditulis tanpa tanda kurung. Artinya, bahwa sekitar $75 \%$ pesanpesan dalam media cergam tersebut dapat difahami oleh khalayak partisipan dalam penelitian ini. Angka sebesar $75 \%$, dalam dunia pendidikan secara umum (rule of thumb), dipandang sebagai ukuran kelulusan dengan katagori baik sampai sangat baik.

Pencapai pemahaman sampai katagori sangat baik itu bukan hanya untuk edisi Bahasa Lampung, tetapi juga untuk empat edisi bahasa lainnya. Atas dasar capaian ini maka dapat dikatakan bahwa perancangan pesan tentang kultur teknis wanatani kopi ini kedalam media buku hiburan cergam menjadi media belajar dapat dikatakan berhasil. Klaim keberhasilan ini dapat dikonfrontir terhadap rendahnya tingkat literasi khalayak, yang menurut Nurhaida dkk (2004), berturut-turut untuk Bahasa Indonesia, Lampung, Semendo, Jawa, dan Sunda sebesar 88, 27, 77, 44, dan 39 kata per menit, seperti dapat di lihat pada Tabel 2 kolom ketiga di atas. Sebagai bahan perbandingan, kemampuan literasi tingkat sarjana biasanya berkisar 300-400 kata per menit. Artinya rancangan buku cergam tersebut berhasil menembus (breakthrough) hambatan literasi yang sangat berat itu untuk mencapai pemahaman terhadap isi pesan tentang wanatani kopi di wilayah resapan yang juga sangat rumit dan sarat dengan permasalahan.

Keberhasilan itu tidak terlepas dari keberhasilan dalam membuat konstruksi media hiburan buku cergam menjadi media belajar, yang dicerminkan oleh ketiga variabel lainnya, yaitu daya tarik (attraction), keterlibatan diri (self involvement), dan penerimaan (acceptability), Variabel daya tarik, tampaknya, punya peran yang sentral yang pertama dari media hiburan, termasuk buku cergam. Ini dapat ditunjukkan oleh hasil akhir uji coba media yang telah dilakukan, bahkan mulai uji coba media yang pertama bahwa rata-rata sekitar 76\% sampai 86\% menyatakan bahwa media ini menarik mereka (setidaknya untuk khalayak petani partisipan/sampel). Bahkan variabel daya tarik ini mencapai $87 \%$ sampai $97 \%$ dalam ujicoba media yang kedua, seperti disajikan dalam Tabel 2. Peran daya tarik yang besar ini, tampaknya, juga didukung oleh desain sampul hasil pilihan khalayak partisipan. Begitu pula dengan penyertaan gambar pada setiap halaman.

Fenomena itu bersesuaian dengan temuan Houts dkk (2006) tentang penggunaan gambar yang sangat mengefektifkan komunikasi dalam bidang kesehatan, bahwa gambar berkaitan secara kuat dengan teks tertulis ataupun terucap, yang bila dibandingkan dengan teks secara tersendiri, gambar dapat secara nyata meningkatkan perhatian atau daya tarik (attraction), dan pengingatan terhadap informasi pendidikan kesehatan. Gambar juga dapat meningkatkan pemahaman (comprehension) manakala gambar memperlihatkan keterhubungan dari ide-idenya ataupun bila memperlihatkan hubungan spasial. Gambar bisa mengefektifkan himbauan ataupun instruksi kesehatan, namun respon yang menyangkut perasaan terhadap gambar memengaruhi, bisa meningkatkan ataupun menurunkan terhadap tar- 
get perilaku. Semua pasien atau komunikan dapat memperoleh manfaat dalam penyertaan gambar, apalagi bagi yang tingkat literasinya rendah, gambar akan sangat membantu pemahaman.

Demikian pula dengan para peneliti lain, juga menemukan kesimpulan yang sama, seperti Satmoko(1995), Retowati (1995), Nugraha (1995), Nurhaida (1995; 1999), Linda dkk (1996), dan Nurhaida (1999), Nurhaida dkk., (2001; 2005b), serta Febrianto dan Rafdinal (2006). Mereka menyingkapkan peranan gambar dalam peningkatan daya tarik dalam komunikasi cetak.

Daya tarik yang tinggi itu, tampaknya menjadi aset awal yang sangat penting bagi partisipan (yang menghadapi hamabatan literasi yang sangat berat itu) untuk mencermati setiap isi pesan yang dituangkan dan setiap halaman media cergam. Dengan begitu, timbul gratifikasi di benak mereka karena isinya menyangkut wanatani kopi yang merupakan perikehidupan mereka sehari-hari. Selanjutnya, gratifikasi ini dapat membangkitkan keterlibatan diri (self involvement), yang mana dalam ujicoba pertama pun sudah sangat tinggi, yaitu $76 \%$ sampai $90 \%$, dan uji coba yang kedua lebih tinggi lagi yang mencapai $87 \%$ sampai $95 \%$.

Sebagai tambahan, penggunaan setting desadesa setempat atau latar belakang fisik, sosial, ekonomi, dan budaya setempat, tampaknya juga mampu meningkatkan keterlibatan dan daya tarik atau gratifikasi terhadap media cergam tersebut. Adanya gratifikasi ini dapat meningkatan peran variabel daya tarik kembali berikutnya, mampu mengalahan barrier yang berat berupa rendahnya tingkat literasi tersebut. Seterusnya, meningkatkan penerimaan akan isinya (yang mencapai rata-rata sekitar 70\% sampai 95\% pada ujicoba media yang kedua).

Dengan pencapaian pemahaman yang cukup tinggi (sekitar 75-81\%, seperti hasil ujicoba media yang kedua dalam Tabel 2 itu), maka kelima edisi ini dapat dikatakan layak sebagai media belajar atau alat bantu komunikasi penyuluhan di wilayah resapan. Penilaian ini didukung oleh tingginya keefektian kelima edisi tersebut, yaitu berturutturut untuk edisi Bahasa Indonesia, Lampung, Semendo, Jawa, dan Sunda sebesar 86\%, 85\%, 89\%, $89 \%$ dan $80 \%$.

\section{Simpulan dan Saran}

Buku cergam sangat efektif dijadikan sebagai media belajar petani kopi di wilayah resapan, yaitu keefektifan masing-masing 85\%, 89\%, 88\%, 89\%, dan $86 \%$ untuk Edisi Bahasa Lampung, Bahasa Jawa, Bahasa Sunda, Bahasa Semendo, dan Bahasa Indonesia. Klaim tingginya keefektifan ini atas dasar tolok ukur tingkat literasi pembacanya yang sangat rendah berturut $27,44,39,77$, dan 88 kata per menit untuk urutan edisi bahasa tersebut.

Saran: (1) lima edisi buku cergam ini perlu diperbanyak selanjutnya disebarluaskan ke masyarakat sekitar hutan di Lampung Barat untuk mengukuhkan kearifan lokal dan melakukan koreksi praktek-praktek wanatani kopi yang keliru di wilayah resapan, dan (2) perlu melakukan penelitian serupa di wilayah resapan yang lain.

\section{Daftar Pustaka}

Affandi, T. K. Manik, B. Rosadi, M. Utomo, M. Senge, dan T. Adachi. 2002a. "Soil erosion under coffee tree managements in humid tropical hillyarea of Lampung Region, Indonesia." Journal of Japanese Society of Soil Physics. Vol. 91:3-14.

Afandi, D. Wiharso, S. Bakri, dan Fahri. 2002b. Evaluation of Profitable and Environmentally Benign Agroforestry Conservation Measures under Coffe Monoculture and Multistarta System. Research Final Report. Cooperation Between Faculty of Agriculture, The University of Lampung and International Centre for Research in Agroforesty (ICRAF) Southeast Asian Regional Research Programme.

Arsyad, S. 2000. Konservasi Tanah dan Air. Bogor: IPB Press.

Bertrand, J. T. 1978. Communications Pretesting. Communication Laboratory, Community and Family Study Center, The University of Chicago.

Delp C., J. Jones. 1996. “Communicating information to patients: the use of cartoon illustrations to improve comprehension of instructions." Acad Emerg Med 1996;3:264-70. 
Depatemen Kehutanan. 2001. Peta Kawasan Hutan dan Perairan Skala 1:500.000. Propinsi Lampung.

Dowse R., M. S. Ehlers. 2001. "The evaluation of pharmaceutical pictograms in a low-literate South African population." Patient Educ Couns 2001;45:87-99.

Febrianto, F. dan Rafdinal. 2006. "Peningkatan komunikasi informasi akuntansi menggunakan gambar kartun." Jurnal Akuntansi dan Keuangan Indonesia 3(1): 128-141.

Houts, P.S., C. C. Doak, L. G. Doak, and M. J. Loscalzo. 2006. The role of picture in improving health communication: A review of research on attention, comprehension, recall and adhenrence. Patient Education and Counseling, 61:173-190.

Joshi, L., S. Suyanto, D.C. Catacutan, dan M. van Noordwijk. 2001. Recognising Local Knowledge and Giving Farmers A Voice in the Policy Development Debate. International Centre for Research in Agroforestry, Southeast Asian Regional Research Programme. Bogor.

Lionberger, H. F. and P. H. Gwin. 1982. Communication Strateges: A Guide for Agricultural Change Agents. The Interstate and Publ. Inc. Danville, Illinois.

Michielutte R, Bahnson J, Digman MB, Schroeder E. 1992. The use of illustrations and narrative text style to improve readability of a health education brochure. J Cancer Educ 1992; 7:251-60.

Michielutte R., J. Bahnson, M. B. Digman, E. Schroeder. 1992. "The use of illustrations and narrative text style to improve readability of a health education brochure." J Cancer Educ 1992; 7:251-60.

Nugraha, B.S. 1995. "Pengaruh Tokoh Utama dan Teknik Penyajian Pesan Grafis dalam Film Slide pada Pengetahuan dan Sikap Para Wanita Tuna Susila tentang Penyakit AIDS di Panti Sosial Karya Wanita "Silih Asih" di Palimanan, Cirebon." The- sis Magister Program Studi Komunikasi Pembangunan Pertanian dan Pedesaan, PPS IPB. Bogor.

Nurhaida, I. 1995. 'Pengaruh BentukPesan dan Bentuk Kesimpulan dalamBuku Cerita Bergambar tentang Konservasi Tanah di Desa Sagara, Kecamatan Argapura, Kabupaten Majalengka.” Thesis Magister. Program Studi Komunikasi Pembangunan Pertanian dan Pedesaan, PPS IPB. Bogor.

Nurhaida, I. 1999. "Pengemasan Desai Pesan Pertanian Konservasi dalam Buku Cerita Bergambar untuk Media Belajar Petani Lahan Kering." Komunitas, Jurnal Penelitian Ilmu Sosial dan Budaya 5(910):20-30

Nurhaida, I., A. Jahi., Ig. Kismono, dan M. S. Padmanegara. 2001. "Pengaruh Pesan yang Menyenangkan dan Pesan yang Menakutkan dalam Buku Cerita Bergambar terhadap Peningkatan Pengetahuan Petani tentang Pertanian Konservasi." Jurnal Lingkungan dan Pembangunan Vol. 21. No. 4:282-296. Pusat Penelitian Sumberdaya Manusia dan Lingkungan, Universitas Indonesia.

Nurhaida, I., S. P. Hariyanto, S. Bakri, A. Junaidi, dan P. Syah. 2004. "Membangun sistem basis data pengetahuan lokal wanatani kopi sebagai landasan utama program komunikasi penyuluhan dengan pendekatan secara bottom up di wilayah resapan Lampung Barat." Laporan Penelitian Hibah Bersaing Perguruan Tinggi. Lembaga Penelitian Unila(TidakDiplukasikan).

Nurhaida, I., S. P. Hariyanto, S. Bakri, A. Junaidi, dan P. Syah. 2005a. "Inventarisasi Kearifan Lokal dalam Praktek Wanatani Kopi sebagai Upaya Pemberian Hak Bicara pada Petani dalam Debat Kelestarian Fungsi Hidro-orologi Wilayah Resapan di Lampung Barat." Jurnal Pembangunan Pedesaan, Vol. 5, No. 2:91-105.

Nyhus, P. J., Sumianto, and R. Tilson. 2003. "Wildlife Knowledge Among Migrant in Way Kambas Southern Sumatera Indonesia: Implication for Conservation." Environmental Conservation. Vol $30: 192-199$. 
Parlato, R. M. B. Parlato, dan B. J. Cain. 1980. Fotonovela and Comic Books. The Use of Popular Graphic Media Development. Office of the Education and Human Resource, Development Support Bereau Agency for International Development, Washington DC.

Pusat Penelitian Tanah dan Agroklimat. 1989. Peta Satuan Tanah dan Lahan Lembar 1010-1011. Land Resource Evaluation and Planning Project I. Badan penelitian dan Pengembangan Pertanian Departemen Pertanian.

Retowati, D. 1995. "Pengaruh Bingkai dan Gambar Kontras Komik pada Peningkatan Pengetahuan Anggota Kelompok Wanita Tani tetang Agribisnis Baby Corn di Kecamatan Banguntapan Kabupaten Bantul, Yoyakarta.” Thesis Magister Program Studi Komunikasi Pembangunan Pertanian dan Pedesaan, PPS IPB. Bogor.
Satmoko, S. 1995. "Pengaruh Tokoh Cerita dan Gambar Kontras Komik pada Peningkatan Pengetahuan Peternak tentang Tatalaksana Beternak Domba di Desa Kulur, Kecamatan Maja Kabupaten Majalengka." Thesis Magister Program Studi Komunikasi Pembangunan Pertanian dan Pedesaan, PPS IPB. Bogor.

Smith, K.H. and M.A. Stutts. 2003. "Effects of short-term cosmetic versus long-term health fears appeal in Fotonovela on the smoking behavior adolescents." Journal of Consumer Behaviour, 3(2):157-177.

Zeffry. 2001. "Komik Indonesia Tahun 1990-an: Deskripsi Keragaman dan Tematik." Makara: Jurnal Penelitian Universitas Indonesia, Vol. 5:30-35. 
